\title{
Chemical Evaluation of Two Tropical Wood Species for Use as Grilling Planks
}

Ulysses Harley Guedes, ${ }^{\mathrm{a}}$ Daniele Melo Santos Paulino, ${ }^{\mathrm{b}}$ Lucas Dellosso Penteado, ${ }^{\mathrm{b}}$ Heloiza Candeia Ruthes, ${ }^{\mathrm{b}}$ Iuri Fazolin Fraga, ${ }^{\mathrm{b}}$ Fernando Junior Resende Mascarenhas, ${ }^{\mathrm{b}}$ Anderson Renato Vobornik Wolenski, ${ }^{\mathrm{c}}$ Raísse Layane de Paula Saraiva, ${ }^{\mathrm{d}}$ Carlos Maviael de Carvalho, ${ }^{\mathrm{d}}$ Vinicius Borges de Moura Aquino, ${ }^{\mathrm{d}, *}$ Francisco Antonio Rocco Lahr, ${ }^{\mathrm{e}}$ and André Luis Christoforo ${ }^{\mathrm{b}}$

This research evaluated the possible use of tropical hardwood species (Myrocarpus frondosus and Ocotea porosa) for grilling plank production. Physical, chemical, and organoleptic properties were evaluated and compared with properties of a well-used wood species for grilling planks, western red cedar (Thuja plicata). For chemical analysis, one technique was used: hydrodistillation. Normality tests and analyses of variance (ANOVA) were used for the comparisons between Thuja plicata and tropical hardwoods. The results of the organoleptic, chemical, and statistical analyses demonstrated the possibility of using Myrocarpus frondosus and Ocotea porosa in grilling plank production.

Keywords: Grilling plank; Apparent density; Brazilian tropical hardwood; Chemical analysis

Contact information: a: Department of Materials Engineering, São Carlos School of Engineering of São Carlos, University of São Paulo (USP), São Carlos/SP, Brazil; b: Department of Civil Engineering (DECiv), Federal University of São Carlos, São Carlos/SP, Brazil; c: Department of Civil Engineering, Federal Institute of Santa Catarina (IFSC), São Carlos/SC, Brazil; d: Araguaia Engineering Institute, Federal University of Southern and Southeastern Pará (UNIFESSPA), Santana do Araguaia/PA, Brazil; e: Department of Structural Engineering, São Carlos School of Engineering of São Carlos, University of São Paulo (USP), São Carlos/SP, Brazil; *Corresponding author: aquino.vini@hotmail.com

\section{INTRODUCTION}

Humans have used wood since antiquity for shelters, agricultural implements, and tools. Its use has increased, as it is used in the furniture and food industries (Lahr et al. 2016; Christoforo et al. 2019; Sthapit 2019). In the food industry, conventional smoking is used to preserve food. This technique enhances the organoleptic process, augmenting the flavor, color, and smell of food (Ledesma et al. 2017).

An alternative means of smoking food is the use of grilling planks. In this process, food is in contact with wood planks, which add to the food complex flavors and moisture. In this case, smoking does not aim to improve the food's lifetime but improves its taste and smell. A grilling plank works as a smoker, as the porous wood surface absorbs moisture and then, when taken to a barbecue or heated oven, releases it with an aromatic smoke (Zoschke 2016). The use of wood grilling planks originated with the Native Americans of the Pacific coast, who used western red cedar (Thuja plicata) wood planks to prepare foods. These foods, such as salmon and vegetables, are tastier, have a soft flavor, and are not burned. In Europe, wood grilling planks have become widely used in restaurants to enhance flavor and smell (Zoschke 2016; Ledesma et al. 2017).

Brazil has the greatest number of wood species in the world (8715 wood species) 
and a large vegetal cover, being 52\% of Brazilian territory (Beech et al. 2017; IBÁ 2017). This amount of wood species and vegetal cover includes a unique diversity of aromatic hardwood trees, such as the Anacardiaceae, Annonaceae, and Meliaceae families. The families Cupressaceae, Abietaceae, and Betulaceae are aromatic softwoods. Considering the diversity of chemical components present in these families, it is easy to select wood species with potential for grilling plank production (Lorenzi 1998; Márquez 2004).

To expand the use of Brazilian tropical woods as grilling planks and to advance the food industry, this study examined the chemical and physical characteristics of Myrocarpus frondosus Allemão and Ocotea porosa wood species and compared their properties with those of Thuja plicata, one of the first wood species used to produce grilling planks.

\section{EXPERIMENTAL}

The wood species Thuja plicata, Myrocarpus frondosus Allemão, and Ocotea porosa were harvested and stored in homogeneous batches at an equilibrium moisture content of 12\%, following the method of Brazilian Standard ABNT NBR 7190 (1997). The batches were deposited at the Wood and Timber Structures Laboratory (LaMEM), University of São Paulo, São Carlos, São Paulo, Brazil.

For the analysis of the organoleptic properties of the wood species, sensory analyses were performed to check the smell, color, taste, grain, and texture, following the parameters described in the literature (Zenid 2019). The wood smell, the main characteristic to be analyzed, was evaluated in three conditions: in natura, after immersion in cold water for $60 \mathrm{~min}$, and during use on a heat source $\left(190^{\circ} \mathrm{C}\right)$, to identify smell changes as would occur with their use as grilling planks. Five male LaMEM employees (ages ranging between 30 years and 60 years) qualified the smell of each species using a hedonic scale: bad, poor, fair, good, or excellent.

Evaluation of apparent density $\left(\rho_{\text {ap }}\right)$ followed the method of the Brazilian standard ABNT NBR 7190 (1997).

For chemical analysis, wood samples were obtained according to TAPPI T $257 \mathrm{~cm}-$ 85 (1985) and TAPPI T $264 \mathrm{~cm}-97$ (1997). The wood was crushed with mill equipment (Wiley SL-31, Piracicaba, Brazil) to reach small particles passing a 30 mesh. The total extractives were evaluated according to TAPPI T 204 (1997). After extractives were removed, the samples were washed with distilled water and dried in an oven at $100{ }^{\circ} \mathrm{C} \pm 2$ ${ }^{\circ} \mathrm{C}$ for $24 \mathrm{~h}$. The extractive content was calculated by mass difference. The resulting extractive-free wood was used to determine Klason lignin content by a modified Klason method (Gomide and Demuner 1986), by the sum of insoluble and soluble lignins. The holocellulose content was determined by the difference between lignin content, ash content, and extractive-free wood mass (Tjeerdsma and Militz 2005). For each chemical analysis, 12 specimens were used, considering hydrodistillation method.

For chemical composition analysis by gas chromatography, one technique was used: hydrodistillation. For the extraction of essential oil from wood species, hydrodistillation was performed, using a graduated Clevenger apparatus protected by aluminum foil. Twenty grams of dry wood of each species was used, ground to 40 mesh weight, with $500 \mathrm{~mL}$ of distilled water. All chemical analyses were performed using gas chromatography-mass spectrometry (GC-MS) (Shimadzu GC-2010AF Plus with TQ8040 sequential mass spectrometer detector, Kyoto, Japan), with a capillary column (Rtx-5ms, $30 \mathrm{~m} \times 0.25 \mathrm{~mm} \times 0.25 \mu \mathrm{m}$, Restek, Bellefonte, USA). 
After qualitative exploratory analysis by GC-MS, the extraction method to be used to obtain a broader chemical profile of the volatile compounds was defined. Extraction was performed with $250 \mathrm{mg}$ of sample moistened with $200 \mu \mathrm{L}$ of ultra-pure water for $30 \mathrm{~min}$ under constant agitation at $80^{\circ} \mathrm{C}$. Then, $1000 \mu \mathrm{L}$ of the volatile compounds were analyzed by GC-MS (Spectrometer TQ8040 detector), with heating from $40{ }^{\circ} \mathrm{C}$ to $120{ }^{\circ} \mathrm{C}$ at a rate of $15{ }^{\circ} \mathrm{C} / \mathrm{min}$ and from $125{ }^{\circ} \mathrm{C}$ to $160{ }^{\circ} \mathrm{C}$ at a rate of $1{ }^{\circ} \mathrm{C} / \mathrm{min}$, remaining at $160{ }^{\circ} \mathrm{C}$ for 2 min. The aforementioned capillary columns were used.

To investigate differences in the wood species based on the experimental results for density, contact angle, and percentages of components (extractives, lignin, and ash), an analysis of variance (ANOVA) was performed, with a 5\% significance level. Equivalence of averages was the null hypothesis, and non-equivalence (of at least two) was the alternative hypothesis. A p-value equal to or greater than the level of significance (0.05) implies acceptance of the null hypothesis, which is refuted otherwise. To validate the ANOVA, the set of values should be evaluated if present a normal distribution, and the homogeneity of the variances of the groups was investigated, with the aid of the AndersonDarling (AD) test, considered at the 5\% significance level.

\section{RESULTS AND DISCUSSION}

\section{Evaluation of Organoleptic Properties of Wood Species}

Tables 1 and 2 present the organoleptic properties of the Brazilian tropical hardwoods and their smells in different conditions of grilling planks.

Table 1. Organoleptic Properties of Brazilian Tropical Hardwoods

\begin{tabular}{|c|c|c|c|c|}
\hline Wood Species & Color & Texture & Taste & Grain \\
\hline $\begin{array}{c}\text { Myrocarpus } \\
\text { frondosus }\end{array}$ & $\begin{array}{c}\text { Dark pinkish } \\
\text { brown }\end{array}$ & Medium to thin & Imperceptible & $\begin{array}{c}\text { Wavy and } \\
\text { irregular }\end{array}$ \\
\hline Ocotea porosa & Dark brown & Medium & Bitter & Direct to reverse \\
\hline
\end{tabular}

Table 2. Smell in Different Conditions

\begin{tabular}{|c|c|c|c|}
\hline Wood Species & Natural & Wet & After Heat Source \\
\hline Myrocarpus frondosus & Excellent & Good & Good \\
\hline Ocotea porosa & Excellent & Good & Good \\
\hline
\end{tabular}

\section{Physical and Chemical Properties of Wood Species}

Table 3 presents the mean values of physical and chemical properties of the wood species and their coefficients of variation $(\mathrm{CV})$.

As shown in Table 3, the apparent densities of Myrocarpus frondosus and Ocotea porosa were higher than that of Thuja plicata. Both Myrocarpus frondosus and Ocotea porosa woods presented contact angles less than $90^{\circ}$ and less than the reference value of Thuja plicata $\left(68.54^{\circ}\right)$, indicating that the surfaces were more wettable than the surface of the reference wood (Thuja plicata) (Wu and Baghdachi 2015). It is also important to consider natural characteristics of the wood, such as chemical composition and surface roughness (Adamson and Gast 1997). 
Table 3. Physical and Chemical Properties of Wood Species

\begin{tabular}{|c|c|c|c|}
\hline \multirow{2}{*}{ Property } & \multicolumn{3}{|c|}{ Wood Species } \\
\cline { 2 - 4 } & $\begin{array}{c}\text { Myrocarpus } \\
\text { frondosus }\end{array}$ & Ocotea porosa & Thuja plicata \\
\hline$\rho_{\mathrm{ap}}\left(\mathrm{g} / \mathrm{cm}^{3}\right)(\mathrm{CV}-\%)$ & $0.88(1.32 \%)$ & $0.66(3.83 \%)$ & $0.46(2.17 \%)$ \\
\hline Mean angle $\left({ }^{\circ}\right)(\mathrm{CV}-\%)$ & $56.75(15.54 \%)$ & $58.75(2.71 \%)$ & $68.54(6.10 \%)$ \\
\hline Extractives $(\%)(\mathrm{CV}-\%)$ & $11.99(6.41 \%)$ & $16.91(2.85 \%)$ & $7.25(3.66 \%)$ \\
\hline Soluble lignin (\%) (CV - \%) & $3.19(0.35 \%)$ & $1.91(23.07 \%)$ & $0.27(3.27 \%)$ \\
\hline Insoluble lignin (\%) (CV - \%) & $30.97(0.98 \%)$ & $43.93(2.88 \%)$ & $34.16(0.74 \%)$ \\
\hline Ashes (\%) (CV - \%) & $0.74(1.00 \%)$ & $0.22(12.54 \%)$ & $0.20(8.67 \%)$ \\
\hline Holocellulose (\%) (CV - \%) & $53.11(4.31 \%)$ & $37.03(6.57 \%)$ & $58.12(1.29 \%)$ \\
\hline
\end{tabular}

Ocotea porosa had the greatest extractive content, indicating more effects on flavor on dishes after wood use as grilling plank. Myrocarpus frondosus presented a higher value compared to Thuja plicata, affecting food flavor. For information of the chemical compositions of the wood species, the lignin, ash, and holocellulose contents were determined. Thuja plicata wood had a holocellulose value of $58.12 \%$, close to that of Myrocarpus frondosus. For Ocotea porosa, the elevated lignin content led to minor holocellulose content (less than 50\%). It is important to highlight that ash and extractive contents may vary due to edaphoclimatic factors (Zau et al. 2014).

The result of Anderson-Darling normality test for all analysis presented a p-value greater than 0.05 , i.e., the results of tropical hardwoods compared with the reference wood species (Thuja plicata) presented a normal distribution, validating the ANOVA results.

Tables 4 to 9 display the results of the ANOVA, comparing the tropical wood species in apparent density, contact angle, and contents of extractives, soluble lignin, insoluble lignin, and ash content.

Table 4. Relation between Apparent Densities

\begin{tabular}{|c|c|}
\hline Wood Species & $p$-value \\
\hline Thuja plicata $\times$ Myrocarpus frondosus & 0.0000 \\
\hline Thuja plicata $\times$ Ocotea porosa & 0.0000 \\
\hline
\end{tabular}

Table 5. Relation between Mean Values of Contact Angle for Wettability

\begin{tabular}{|c|c|}
\hline Wood Species & $p$-value \\
\hline Thuja plicata $\times$ Myrocarpus frondosus & 0.4201 \\
\hline Thuja plicata $\times$ Ocotea porosa & 0.5838 \\
\hline
\end{tabular}

Table 6. Relation between Extractive Contents

\begin{tabular}{|c|c|}
\hline Wood Species & $p$-value \\
\hline Thuja plicata $\times$ Myrocarpus frondosus & 0.0000 \\
\hline Thuja plicata $\times$ Ocotea porosa & 0.0000 \\
\hline
\end{tabular}

Table 7. Relation between Soluble Lignin Contents

\begin{tabular}{|c|c|}
\hline Wood Species & $p$-value \\
\hline Thuja plicata $\times$ Myrocarpus frondosus & 0.0000 \\
\hline Thuja plicata $\times$ Ocotea porosa & 0.0000 \\
\hline
\end{tabular}


Table 8. Relation between Insoluble Lignin Contents

\begin{tabular}{|c|c|}
\hline Wood Species & $p$-value \\
\hline Thuja plicata $\times$ Myrocarpus frondosus & 0.0001 \\
\hline Thuja plicata $\times$ Ocotea porosa & 0.0000 \\
\hline
\end{tabular}

Table 9. Relation between Ash Contents

\begin{tabular}{|c|c|}
\hline Wood Species & p-value \\
\hline Thuja plicata $\times$ Myrocarpus rondosus & 0.0000 \\
\hline Thuja plicata $\times$ Ocotea porosa & 0.6213 \\
\hline
\end{tabular}

As shown in Table 4, there was a significant difference between the apparent densities of Myrocarpus frondosus, Ocotea porosa, and Thuja plicata. For values of mean contact angle (Table 5), both wood species presented values close to the Thuja plicata value. For extractive content, insoluble lignin, and soluble lignin values (Tables 6 to 8), Myrocarpus frondosus and Ocotea porosa values were significantly different from the reference values (Thuja plicata). The ash content of Myrocarpus frondosus was significantly different from that of Thuja plicata, which did not differ significantly from that of Ocotea porosa. The GC-MS results are presented in Tables 10, 11, and 12.

Table 10. Compounds Detected in Myrocarpus frondosus Essential Oils Extracted by Hydrodistillation

\begin{tabular}{|c|c|}
\hline Compound $^{\text {b }}$ & I.R. $^{\text {a }}$ \\
\hline $\begin{array}{c}\text { 1,1-dimethyl 3- } \\
\text { chloropropane }\end{array}$ & 807 \\
\hline 4-methyl-2-pentanol & 811 \\
\hline 5-methoxy-2-pentanone & 1008 \\
\hline Nerolidol & 1655 \\
\hline
\end{tabular}

(a) Kovats indexes (KI) on capillary column; (b) compounds listed in evolution order in capillary column; I.R. (infrared spectra interpretation);

Table 11. Compounds Detected in Ocotea porosa Essential Oils Extracted by Hydrodistillation

\begin{tabular}{|c|c|c|c|c|c|}
\hline Compound $^{\mathrm{b}}$ & I.R. $^{\mathrm{a}}$ & Compound $^{\mathrm{b}}$ & I.R. $^{\mathrm{a}}$ & Compound $^{\mathrm{b}}$ & I.R. $^{\mathrm{a}}$ \\
\hline $\begin{array}{c}\text { 1,1-dimethyl-3- } \\
\text { chloropropanol }\end{array}$ & 807 & Guaiol & 1695 & Hinesol & 1730 \\
\hline $\begin{array}{c}\text { 4-methyl-2- } \\
\text { pentanol }\end{array}$ & 811 & Ledol & 1700 & T-cadinol & 1736 \\
\hline $\begin{array}{c}\text { 5-methoxy-2- } \\
\text { pentanone }\end{array}$ & 1008 & Isoshyobunone & 1705 & 1 -Naphthalenol & 1740 \\
\hline Eucalyptol & 1038 & Cubenol & 1711 & Nerolidol & 1746 \\
\hline a-copaene & 1474 & Y-eudesmol & 1715 & a-Cadinol & 1748 \\
\hline Naftalene & 1612 & Cubedol & 1723 & $\begin{array}{c}\text { Selina-3,7(11)- } \\
\text { diene }\end{array}$ & 1750 \\
\hline Trans-calamenene & 1620 & $\alpha$-acorenol & 1726 & $\beta$-bisabolol & 1766 \\
\hline$\alpha$-calacorene & 1639 & & & Naphthalene & 1768 \\
\hline
\end{tabular}

(a) Kovats indexes (KI) on capillary column; (b) compounds listed in evolution order in capillary column; I.R. (infrared spectra interpretation); 
Table 12. Compounds Detected in Thuja plicata Essential Oils Extracted by Hydrodistillation, Soxhlet, and Headspace

\begin{tabular}{|c|c|c|c|c|c|}
\hline Compound $^{\mathrm{b}}$ & I.R. $^{\mathrm{a}}$ & Compound $^{\mathrm{b}}$ & I.R. $^{\mathrm{a}}$ & Compound $^{\mathrm{b}}$ & I.R. $^{\mathrm{a}}$ \\
\hline $\begin{array}{c}\text { 1,1-dimethyl-3- } \\
\text { chloropropanol }\end{array}$ & 807 & Terpinen-4-ol & 1274 & $\begin{array}{c}\text { Bicyclo[3.1.1]heptan } \\
\text {--2-methanol }\end{array}$ & 1340 \\
\hline 2-pentanol & 811 & a-Terpineol & 1284 & 3-caren-10-al & 1361 \\
\hline Norbornane & 954 & Myrtenol & 1297 & $\begin{array}{c}\text { Cyclohexene- } \\
\text { carboxaldehyde }\end{array}$ & 1374 \\
\hline o-cymene & 1029 & Carvone & 1309 & $\begin{array}{c}\text { Phenol, 2-ethyl-4,5- } \\
\text { dimethyl- }\end{array}$ & 1398 \\
\hline $\begin{array}{c}\text { 2,7,7-trimethylbicyclo } \\
\text { 2.2.1]heptan-2-ol }\end{array}$ & 1218 & $\begin{array}{c}\text { 2-methyl-3- } \\
\text { phenylpropanal }\end{array}$ & 1337 & $\begin{array}{c}\text { Benzoic acid, 2,4,5- } \\
\text { trimethyl- }\end{array}$ & 1420 \\
\hline Endo-borneol & 1263 & Furadane & 1514 & $\begin{array}{c}\text { Acetovanillone } \\
\text { acetate }\end{array}$ & 1426 \\
\hline Nerolidol & 1656 & & & $\begin{array}{c}\text { Benzoic acid, 4-(1- } \\
\text { methylethyl)- }\end{array}$ & 1477 \\
\hline
\end{tabular}

(a) Kovats indexes (KI) on capillary column; (b) compounds listed in evolution order in capillary column; I.R. (infrared spectra interpretation of chemical compound);

As shown in Table 10, from the Myrocarpus frondosus extraction by hydrodistillation, it was possible to identify four compounds.

The results of the GC-MS tests presented in Table 11 showed that the species Ocotea porosa contained compounds identified in all the extraction techniques used. From hydrodistillation for Ocotea porosa, 23 compounds were identified, the majority of them, in decreasing order: guaiol (100\%), ledol (24.69\%), and $\tau$-cadinol $(50.92 \%)$.

The results of the GC-MS tests presented in Table 12 showed that, through hydrodistillation for Myrocarpus frondosus, 20 compounds were identified, the most of them being, in decreasing order: myrtenol (100\%), $\alpha$-terpineol (49.76\%), and terpinen-4ol $(26.24 \%)$.

The percentages presented represent chemical content of each compound. The higher content stands out for higher percentage (100\%) and so decreasing for other contents.

Nerolidol was present in all wood species. Nerolidol is allowed by the United States Food and Drug Administration (FDA) to be used in the food industry as a food flavoring agent. Then, it supports the possible use of tropical wood species as grilling planks in the food industry, which can improve foods' preparations (Chan et al. 2016; Ušjak et al. 2017; Azzi et al. 2018).

Also, otherwise Thuja plicata, Myrocarpus frondosus, and Ocotea porosa did not contain, according chemical analysis, toxic volatile chemical compounds such thujone, which is toxic for human being even at low levels (SCE 2002). This absence enables their use as grilling planks, with similar apparent density of a well-known wood specie already used for grilling planks and satisfactory organoleptic properties for use on planks. Also, a lower apparent density for Myrocarpus frondosus and Ocotea porosa contributes a good impregnation process during plank manufacture and lower weight, reducing costs along productive process and transportation. 


\section{CONCLUSIONS}

1. Chemical analysis supported the possible use of Myrocarpus frondosus and Ocotea porosa tropical hardwoods for production of grilling planks. They have elevated amounts of extractives, which are important for organoleptic properties, such as taste and smell.

2. Apparent density of Myrocarpus frondosus and Ocotea porosa were close to the reference value of Thuja plicata wood specie, being interesting the wood species with lower apparent density.

3. Gas chromatography indicated the presence of nerolidol, used as a flavoring agent in several foods, in all wood species and the absence of the compound thujone, which is toxic for humans. In addition, organoleptic properties were satisfactory supporting the use of Myrocarpus frondosus and Ocotea porosa wood species for grilling plank production.

\section{REFERENCES CITED}

ABNT NBR 7190 (1997). "Projeto de estruturas de madeira," Associação Brasileira de Normas Técnicas, Rio de Janeiro, Brazil.

Adamson, A. W., and Gast, A. P. (1997). Physical Chemistry of Surfaces, $6^{\text {th }}$ Ed., John Wiley \& Sons, Inc., New York, NY, USA.

Azzi, J., Auezova, L., Danjou, P.-E., Fourmentin, S., and Greige-Gerges, H. (2018). "First evaluation of drug-in-cyclodextrin-in-liposomes as an encapsulating system for nerolidol," Food Chemistry 255, 399-404. DOI: 10.1016/j.foodchem.2018.02.055

Beech, E., Rivers, M., Oldfield, S., and Smith, P. P. (2017). "GlobalTreeSearch: The first complete global database of tree species and country distributions," Journal of Sustainable Forestry 36(5), 454-489. DOI: 10.1080/10549811.2017.1310049

Chan, W.-K., Tan, L. T.-H., Chan, K.-G., Lee, L.-H., and Goh, B.-H. (2016). "Nerolidol: A sesquiterpene alcohol with multi-faceted pharmacological and biological activities," Molecules 21(5). DOI: 10.3390/molecules21050529

Christoforo, A. L., Aquino, V. B. d. M., Wolenski, A. R. V, Araujo, V. A. D., and Lahr, F. A. R. (2019). "Evaluation of the Peltophorum vogelianum Benth. wood species for structural use," Engenharia Agrícola 39(6), 763-768. DOI: 10.1590/1809-4430eng.agric.v39n6p763-768/2019

Gomide, J. L., and Demuner, B. J. (1986). "Determinação do teor de lignina em material lenhoso: Método Klason modificado," O Papel, 47(8), 36-38.

IBÁ (2017). Relatório 2017, Indústria Brasileira de Árvores (IBÁ), Brasilia, Brazil.

Lahr, F. A. R., Arroyo, F. N., Almeida, T. H. d., Almeida Filho, F. M. d., Mendes, I. S., and Christoforo, A. L. (2016). "Full characterization of Erisma uncinatum Warm Wood Specie," International Journal of Materials Engineering, 6(5) 147-150. DOI: 10.5923/j.ijme.20160605.01

Ledesma, E., Rendueles, M., and Díaz, M. (2017). "Smoked food," in: Current Developments in Biotechnology and Bioengineering: Food and Beverages Industry, A. Pandey, M. Á. Sanromán, G. Du, C. R. Soccol, and C.-G. Dussap (eds.), Elsevier, Amsterdam, The Netherlands, pp. 201-243. DOI: 10.1016/B978-0-444-636669.00008-X 
Lorenzi, H. (1998). Árvores Brasileiras: Manual de Identificação e Cultivo de Plantas Arbóreas Nativas do Brasil, Plantarum, São Paulo, Brazil.

Márquez, M. D. R. (2004). Plantas Aromaticas: Tratado de Aromaterapia Científica, Kier, Buenos Aires, Argentina.

SCE. (2002) "Opinion of the Scientific Committee on Food on Thujone" [Internet]. European Comission. Brussels, Belgium; Available from: http://ec.europa.eu/food/fs/sc/scf/out120_en.pdf

Sthapit, E. (2019). "Memories of gastronomic experiences, savoured positive emotions and savouring processes," Scandinavian Journal of Hospitality and Tourism 19(2), 115-139. DOI: 10.1080/15022250.2017.1402702

TAPPI T 204 (1997). "Solvent extractives of wood and pulp,” TAPPI Press, Atlanta, GA, USA.

TAPPI T 257 cm-85 (1985). "Sampling and preparing wood for analysis," TAPPI Press, Atlanta, GA, USA.

TAPPI T 264 cm-97 (1997). "Preparation of wood for chemical analysis," TAPPI Press, Atlanta, GA, USA.

Tjeerdsma, B. F., and Militz, H. (2005). "Chemical changes in hydrothermal treated wood: FTIR analysis of combined hydrothermal and dry heat-treated wood," Holz als Roh- und Werkstoff 63(2), 102-111. DOI: 10.1007/s00107-004-0532-8

Ušjak, L., Petrović, S., Drobac, M., Soković, M., Stanojković, T., Ćirić, A., and Niketić, M. (2017). "Edible wild plant Heracleum pyrenaicum subsp. orsinii as a potential new source of bioactive essential oils," Journal of Food Science and Technology 54(8), 2193-2202. DOI: 10.1007/s13197-017-2610-z

Wu, L., and Baghdachi, J. (eds.) (2015). Functional Polymer Coatings: Principles, Methods, and Applications, John Wiley \& Sons, Inc., Hoboken, NJ, USA. DOI: 10.1002/9781118883051

Zau, M. D. L., Vasconcelos, R. P. d., Giacon, V. M., and Lahr, F. A. R. (2014). "Avaliação das propriedades química, física e mecânica de painéis aglomerados produzidos com resíduo de madeira da Amazônia - Cumaru (Dipteryx odorata) e resina poliuretana à base de óleo de mamona," Polímeros 24(6), 726-732. DOI: 10.1590/0104-1428.1594

Zenid, G. J. (2019). Identificação e Grupamento das Madeiras Serradas Empregadas na Construção Civil Habitacional na Cidade de São Paulo, Master's Dissertation, Universidade de São Paulo, Piracicaba, Brazil. DOI: 10.11606/D.11.2019.tde20191218-140415

Zoschke, H. (2016). "Grillen \& BBQ, Sonstiges," (http://pepperworld.com/mit-dergrillplanke-grillen-wie-die-profis-teil-1), Accessed 6 Jan 2021.

Article submitted: May 18, 2021; Peer review completed: September 11, 2021; Revised version received and accepted: October 18, 2021; Published: October 22, 2021.

DOI: $10.15376 /$ biores.16.4.8219-8226 